\section{Beyond sharing Earth observations}

To improve the accuracy of products derived from shared satellite observations of Earth (see M. A. Wulder and N. C. Coops Nature 513, 30-31; 2014), governments and research institutes also need to share calibration and validation data. Such data are measured on the ground or interpreted from highresolution satellite imagery.

Satellite images are now available at very high resolution. Crowd-sourced calibration and validation data would vastly improve classification algorithms as well as the accuracy of landcover products.

Enhanced accuracy would enable remote sensing to be better used for monitoring biodiversity loss and ecosystem dynamics, for example, and for other applications that depend on baseline and changing land cover.

Efforts such as the Global Observation of Forest Cover and Land Dynamics and Geo-Wiki.org are working in this direction. More initiatives are needed to unlock the incredible amount of data that remain confined within institutes and agencies.

Linda See, Steffen Fritz, Ian McCallum International Institute for Applied Systems Analysis, Laxenburg, Austria. see@iiasa.ac.at

\section{Renewables: costly long-distance power}

In my view, the long-distance transmission of intermittent renewable electricity is not a costeffective way to reduce emissions (J. A. Mathews and H. Tan Nature 513, 166-168; 2014). Power transmission is highly inefficient, with $3.5 \%$ or more being lost from an ultra-high-voltage line over 1,000 kilometres (see go.nature.com/dli4we).

China can produce renewables cheaply because of economies of scale, market expansion, low labour costs and minimal environmental regulation. But this may not be sustainable. Already, the availability of resources and competitive utilization are challenging.

Electricity demands vary in different regions, from low in the wind-rich north and west of the country, to high in coastal areas. The cost of transmitting electricity over such vast distances is unlikely to be offset by increasing wind-turbine operating hours.

The remote use of renewable electricity might be much more expensive per unit than electricity produced by conventional generators, even considering the social cost of carbon. In most cases, the costs will also be higher compared with locally generated renewable energy, even when those resources are limited. Shuwei Zhang Draworld Environment Research Center, Beijing, China.

shuwei.zh@gmail.com

\section{Renewables: can harm environment}

The large-scale generation of renewable energy (J. A. Mathews and H. Tan Nature 513, 166-168; 2014) can damage the environment.

In China, for instance, giant hydropower projects include 25 hydropower stations within 100 kilometres of one another on the Jinsha River, and 90 stations on 66 tributaries of the Salween River. These stations pose a large risk to local and regional hydrology, geology and ecology (see, for example, Nature 513, 154-155; 2014).

Conversion of wind kinetic energy into electricity generates noise, affecting local communities and migratory birds, and even local weather and climate (L. Zhou et al. Nature Clim. Change 2, 539-543; 2012). Furthermore, the manufacture of solar photovoltaic products can cause serious environmental pollution (see H. Yang et al.
Nature 509, 563; 2014).

Development of renewableenergy projects should always take into account the long-term effects on the local natural, social and technological conditions. Xin Miao Harbin Institute of Technology, Harbin, China. xin.miao@aliyun.com

\section{Renewables: the sky is the limit}

The International Energy Agency (IEA) claims in a report that up to $45 \%$ of power generated annually could come from renewable energy sources in some advanced economies without significantly increasing long-term power-system costs (The Power of Transformation; IEA, 2014). This raises the possibility that certain regions could be using $100 \%$ renewables during our lifetime (see also J. A. Mathews and H. Tan Nature 513, 166-168; 2014).

This possibility is backed, for instance, by analyses in India by the conservation group WWF and the Energy and Resources Institute (see go.nature.com/7shcug), and in Australia by the Australian Energy Market Operator (see go.nature.com/wttlps).

As noted in the IEA report, progress in integrating renewables depends on cost constraints, local weather and daylight patterns, and the flexibility of existing power systems.

Don Gunasekera Victoria University, Melbourne, Australia. don.gunasekera@vu.edu.au

\section{Photosynthesis and the Nobel physicist}

It is not widely known that the Nobel-prizewinning atomic physicist James Franck (see '50 Years Ago' Nature 512, 381 ; 2014) spent 30 years investigating photosynthesis (see J. L. Rosenberg Photosynth. Res. 80, 71-76; 2004).

Dining at the University of Chicago's Quadrangle Club, Franck met the distinguished scientist and Biochemistry textbook author Lubert Stryer, then a student and part-time waiter. Stryer told me that Franck chatted to him about his research into how plants convert visible light into chemical energy, adding that it might be useful to Stryer one day.

Later, Stryer took advantage of Franck's unfinished work to investigate other photochemical reactions, notably going on to elucidate the function of the $G$ protein that transduces the light signal in visual excitation (see L. Stryer J. Biol. Chem. 287, 15164-15173; 2012).

Min-Liang Wong National Chung-Hsing University, Taiwan. mlwong@dragon.nchu.edu.tw

\section{Maths medal boosts Brazilian morale}

This year has been momentous for Brazil. We lost the World Cup on our own turf, yet one of our mathematicians received the highest scientific honour ever to be awarded to a Brazilian. Scientists now stand a chance of competing with footballers as role models for Brazil's youngsters.

Artur Avila, who also has French nationality, won the Fields Medal, the most prestigious prize in maths (see Nature http://doi. org/vn4; 2014). This triumph has sent a wave of motivation through students and boosted the morale of educators and scientists. Science, as well as football, can offer a route out of poverty. Tiago Campos Pereira University of São Paulo, Brazil. tiagocampospereira@ffclrp.usp.br

\section{CORRECTION}

The Outlook article 'Early warning system' (Nature 513, S4-S6; 2014) wrongly said that a low-dose CT scan gives the same radiation exposure as one transatlantic flight. In fact, radiation on such a flight is $\sim 50$ microsieverts, 30 times less than from a low-dose scan. 